\title{
STUDIES ON BACTERIAL CELL WALL INHIBITORS
}

\author{
X. PROPERTIES OF PHOSPHO-N-ACETYLMURAMOYL- \\ PENTAPEPTIDE-TRANSFERASE IN PEPTIDOGLYCAN \\ SYNTHESIS OF BACILLUS MEGATERIUM AND ITS \\ INHIBITION BY AMPHOMYCIN*
}

\author{
Haruo Tanaka, Ruiko Ōina, Shigekazu Matsukura**, \\ JUNJI INOKOSHI and SATOSHI ŌMURA*** \\ School of Pharmaceutical Sciences, Kitasato University, \\ and the Kitasato Institute, Minato-ku, Tokyo 108, Japan
}

(Received for publication May 10, 1982)

\begin{abstract}
The phospho- $N$-acetylmuramoyl-pentapeptide-transferase from Bacillus megaterium $\mathrm{KM}$ was characterized by the transfer reaction. The particulate enzyme preparation had the activity to transfer phospho- $N$-acetylmuramoyl-pentapeptide from UDP- $N$-acetylmuramoylpentapeptide to undecaprenoid-1-ol-phosphate. The optimum $\mathrm{pH}$ for activity was about 8.5. The reaction required the presence of $\mathrm{Mg}^{2+}$ and an $\mathrm{SH}$-protector. With $25 \mathrm{mM} \mathrm{Mg}^{2+}$ the maximum activity was observed. The reaction was reversible and so the addition of UMP decreased the formation of undecaprenoid-1-ol-diphospho- $N$-acetylmuramoyl-pentapeptide.

Amphomycin inhibited non-competitively the transferase for the substrate UDP- $N$ acetylmuramoyl-pentapeptide.
\end{abstract}

In the previous papers ${ }^{1 \sim 3)}$, we have described that amphomycin ${ }^{4,5)}$ is a specific inhibitor of bacterial cell wall peptidoglycan synthesis ${ }^{1,2)}$ and that it inhibits phospho-MurNAc-pentapeptide-transferase (UDP- $N$-acetylmuramoyl-L-alanyl-D- $\gamma$-glutamyl- $\gamma$-lysyl (or meso-diaminopimelyl)-D-alanyl-D-alanine: undecaprenoid-1-ol-phosphate phospho- $N$-acetylmuramoyl-pentapeptide-transferase, EC 2.7.8.13), the first step of a lipid cycle in peptidoglycan synthesis in Bacillus ${ }^{3)}$ : the step is of interest because it catalyzes the transfer of a hydrophilic substrate into the lipophilic environment of the membrane.

The properties of the enzyme have been characterized only with particulate and solubilized preparations from Staphylococcus aureus ${ }^{8)}$ and with a solubilized enzyme from Escherichia coli ${ }^{7)}$. However, the enzymes from Gram-positive rods have never been reported. So, the authors examined the properties of the transferase from the Gram-positive $\operatorname{rod} B$. megaterium. It was found that the enzyme could be differentiated from that of $S$. aureus although they both catalyze the following reaction.

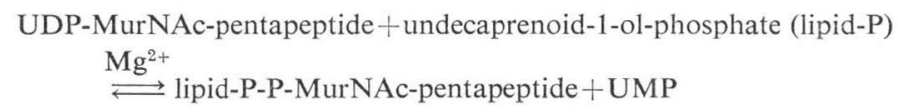

For example, the transferase from $S$. aureus is activated by monovalent cations such as $\mathrm{K}^{+}$and $\mathrm{NH}_{4}{ }^{+8)}$, but the enzyme from $B$. megaterium KM is not stimulated by these cations.

* Part IX appeared in J. Biochem. 88: 565 570, 1980. This work was supported in part by a research grant from the Ministry of Education, Science and Culture of Japan.

** Present address: Central Research Institute, Suntory Ltd., Shimamoto-cho, Osaka 618, Japan

*** To whom all correspondence should be addressed.

Abbreviations: MurNAc-pentapeptide or MurNAc-L-Ala-D- $\gamma-G l u-m e s o-D p m-D-A l a-D-A l a$ for $N$-acetylmuramoyl-L-alanyl-D- $\gamma$-glutamyl-meso-diaminopimelyl-D-alanyl-D-alanine; lipid-P for undecaprenoid-l-ol phosphate. 
The present paper deals with the properties of the enzyme of B. megaterium KM and with the mode of its inhibition by amphomycin.

-

Materials and Methods

Bacterial Strain

B. megaterium KM was obtained from Dr. P. E. ReYnolds, Department of Biochemistry, University of Cambridge, England.

Chemicals

Amphomycin (Na salt) was given by Dr. L. DelCambe, International Center of Information of Antibiotics, Belgium. Other chemicals were obtained commercially.

Radiochemicals

(DL + meso)-2,6-Diamino-[G- $\left.{ }^{3} \mathrm{H}\right]$ pimelic acid hydrochloride $(45 \mathrm{Ci} / \mathrm{mmole})$ was obtained from Commissariat a L'Energie Atomique, France, UDP-MurNAc-L-Ala-D- $\gamma$-Glu-meso- $\left[{ }^{3} \mathrm{H}\right] \mathrm{D}$ pm-D-Ala$\mathrm{D}$-Ala was prepared according to the method of REYNOLDS ${ }^{9)}$ with some modification. An example of the preparation is described below. A culture $(1 \%)$ of $B$. megaterium $\mathrm{KM}$ grown overnight at $37^{\circ} \mathrm{C}$ in a medium ( $\mathrm{pH} \mathrm{5.0),} \mathrm{containing} 2.0 \%$ dehydrated Nutrient broth (Difco), $0.5 \%$ yeast extract, $200 \mu \mathrm{g} /$ $\mathrm{ml}$ of L-lysine and $25 \mu \mathrm{g} / \mathrm{ml}$ of meso-diaminopimelic acid, was transferred into the same fresh medium $\left(100 \mathrm{ml}\right.$ in a $500-\mathrm{ml}$ Sakaguchi flask), and incubated with shaking at $37^{\circ} \mathrm{C}$ until the absorbance at $660 \mathrm{~nm}$ reached 0.4 . The cells were harvested by centrifugation and washed twice with $0.01 \mathrm{M}$ potassium phosphate buffer ( $\mathrm{pH} 7.0$ ) containing $1 \mathrm{~mm} \mathrm{MgCl}_{2}$ and $0.8 \% \mathrm{NaCl}$. The washed cells were suspended at the concentration of $100 \mathrm{mg}$ wet cells per $\mathrm{ml}$ in a medium, containing $4 \mathrm{mg}$ of $\mathrm{KCl}, 4 \mathrm{mg}$ of $\mathrm{MgCl}_{2}, 2 \mathrm{mg}$ of $\mathrm{NH}_{4} \mathrm{Cl}, 0.15 \mathrm{mg}$ of $\mathrm{Na}_{2} \mathrm{SO}_{4}, 0.35 \mathrm{mg}$ of $\mathrm{Na}_{2} \mathrm{HPO}_{4} \cdot 12 \mathrm{H}_{2} \mathrm{O}, 10 \mathrm{mg}$ of glucose, $0.04 \mathrm{mg}$ of uracil, $0.125 \mathrm{mg}$ of L-alanine, $0.125 \mathrm{mg}$ of L-glutamic acid, $0.2 \mathrm{mg}$ of L-lysine, $0.05 \mathrm{mg}$ of chloramphenicol, $0.02 \mathrm{mg}$ of vancomycin and $2 \mu \mathrm{Ci}$ (DL + meso)-2,6-diamino-[G- $\left.{ }^{8} \mathrm{H}\right]$ pimelic acid hydrochloride per $\mathrm{ml}$, and then incubated with aeration at $37^{\circ} \mathrm{C}$ for 35 minutes. The incubated cells were harvested by centrifugation, extracted overnight with $5 \%$ trichloroacetic acid at $4{ }^{\circ} \mathrm{C}$, and then centrifuged at $4,000 \times g$ for 10 minutes. After the supernatant fluid had been washed with ethyl ether to remove the remaining trichloroacetic acid and adjusted to $\mathrm{pH} 7.0$ with $1 \mathrm{~N} \mathrm{NaOH}$, it was submitted to column chromatography on Dowex $1 \times 2\left(\mathrm{Cl}^{-}\right)$as described by STROMINGer et al. ${ }^{10)}$ Fractions containing UDPMurNAc-pentapeptide were further submitted to gel filtration through Sephadex G-10 and paper chromatography using Toyo Roshi No. 51A paper and iso-butyric acid-acetic acid-1 $\mathrm{N} \mathrm{NH}_{4} \mathrm{OH}$ $(10: 1: 5)$ as the developing solvent. The extract from the paper chromatogram ( Rf 0.25) was desalted by gel filtration with Sephadex G-10 to give a solution of UDP-MurNAc-L-Ala-D- $\gamma-G l u-m e s o-\left[{ }^{3} \mathrm{H}\right] \mathrm{Dpm}-$ D-Ala-D-Ala (980 $\mu \mathrm{l}, 0.7 \mu$ mole, specific activity: $12.1 \mathrm{mCi} / \mathrm{mmole})$.

Assay of Phospho-MurNAc-pentapeptide-transferase with a Particulate Fraction from $B$. megaterium $\mathrm{KM}$

The assay was performed using a particulate fraction prepared from B. megaterium KM according to the method described by $\mathrm{OKA}^{11)}$. The assay procedures are as follows unless otherwise stated. A reaction mixture $(30 \mu \mathrm{l})$, containing 0.11 or $0.33 \mathrm{~mm}$ UDP-MurNAc- $\left[{ }^{3} \mathrm{H}\right]$ pentapeptide $(12.1 \mathrm{mCi} /$ mmole), $250 \mathrm{~mm}$ tris- $\mathrm{HCl}$ buffer ( $\mathrm{pH} 8.5$ ), $25 \mathrm{mM} \mathrm{MgCl}_{2}, 1.0 \mathrm{~mm}$ dithiothreitol and $10 \mu \mathrm{l}$ of the particulate fraction $\left(200 \sim 300 \mu \mathrm{g}\right.$ of protein), was incubated for 3 minutes at $25^{\circ} \mathrm{C}$. After the reaction was stopped by addition of $20 \mu \mathrm{l}$ of $6 \mathrm{M}$ pyridinium acetate $(\mathrm{pH} 4.2)$, the lipid intermediate (undecaprenoid1-ol diphosphate-MurNAc-pentapeptide) formed was extracted twice with $100 \mu \mathrm{l}$ of $n$-butanol. The extracts were transferred to a scintillation vial and dried. The radioactivity was determined using a toluene scintillation fluid with a liquid scintillation counter (Aloka ASC-651).

\section{Results}

Properties of Phospho-MurNAc-pentapeptide-transferase from B. megaterium KM A particulate enzyme preparation from $S$. aureus is known to catalyze the following two reactions ${ }^{8)}$. 
(1) Transfer reaction

UDP-MurNAc-pentapeptide + lipid-P $\stackrel{\mathrm{Mg}^{2+}}{\rightleftarrows}$ lipid-P-P-MurNAc-pentapeptide + UMP

(2) Exchange reaction

$\left[{ }^{3} \mathrm{H}\right]$ UMP + UDP-MurNAc-pentapeptide $\rightleftarrows\left[{ }^{3} \mathrm{H}\right]$ UDP-MurNAc-pentapeptide + UMP

The phospho-MurNAc-pentapeptide-transferase from B. megaterium KM was characterized by the transfer reaction. The particulate enzyme preparation had the activity to transfer phospho-MurNAcpentapeptide from UDP-MurNAc-pentapeptide to lipid-P as shown in Fig. 1. The reaction proceeded in a straight line for 4 minutes at $25^{\circ} \mathrm{C}$ at pH 8.5, and then the velocity was decreased. In the following

Fig. 1. Transfer of phospho-MurNAc-pentapeptide from UDP-MurNAc-pentapeptide to lipid-P as a function of time.

The reaction mixture contained $0.11 \mathrm{~mm}$ UDPMur-NAc- $\left[{ }^{3} \mathrm{H}\right]$ pentapeptide.

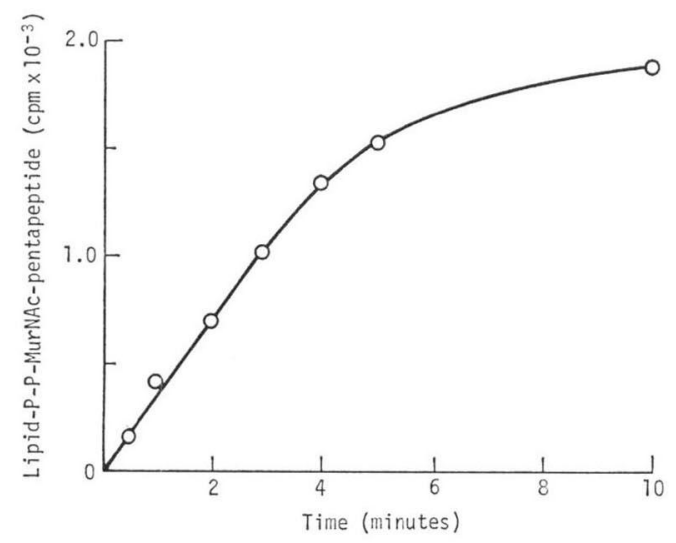

Fig. 2. Effect of $\mathrm{pH}$ on the phospho-MurNAcpentapeptide-transferase activity.

The reaction mixture contained $0.11 \mathrm{~mm}$ UDPMurNAc- $\left[{ }^{3} \mathrm{H}\right]$ pentapeptide. Incubation time: 5 minutes; $\bigcirc, 0.1 \mathrm{M}$ tris- $\mathrm{HCl}$ buffer; $\triangle, 0.1 \mathrm{~m}$ sodium citrate buffer.

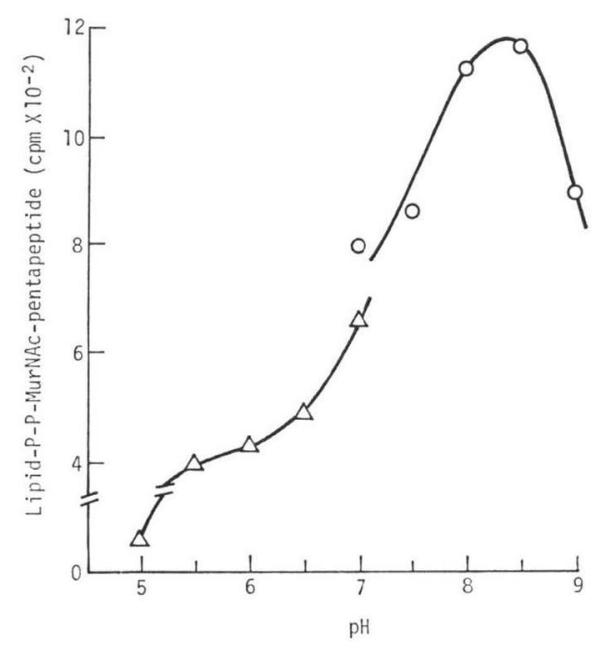

Table 1. Requirements for the phospho-MurNAcpentapeptide-transferase activity.

Complete reaction mixture: $0.11 \mathrm{~mm}$ UDPMurNAc- $\left[{ }^{3} \mathrm{H}\right]$ pentapeptide $(12.1 \mathrm{mCi} / \mathrm{mmole}), 0.1 \mathrm{M}$ tris- $\mathrm{HCl}$ buffer ( $\mathrm{pH} 8.5$ ), $25 \mathrm{~mm} \mathrm{MgCl}_{2}, 10 \mathrm{mM}$ dithiothreitol and $10 \mu \mathrm{l}$ of particulate fraction (153 $\mu \mathrm{g}$ of protein). Total volume: $35 \mu \mathrm{l}$.

\begin{tabular}{ll|r}
\hline \multicolumn{1}{c|}{ Reaction mixture } & $\begin{array}{c}\text { Lipid-P-P-MurNAc- } \\
\text { pentapeptide } \\
\text { cpm (\%) }\end{array}$ \\
\hline Complete & & $1,003(100)$ \\
Omission & $\mathrm{Mg}^{2+}$ & $179(18)$ \\
& Dithiothreitol & $329(33)$ \\
& $\begin{array}{c}\text { Particulate } \\
\text { fraction }\end{array}$ & $13(1)$ \\
Addition & 2.5 mM UMP & $191(19)$ \\
& 25 mM UMP & $37(4)$ \\
& 0.2 mM ATP & $931(93)$ \\
\hline
\end{tabular}

Table 2. Effect of monovalent ions on the phosphoMurNAc-pentapeptide-transferase activity.

Basal reaction mixture: $0.33 \mathrm{~mm}$ UDP-MurNAc$\left[{ }^{3} \mathrm{H}\right]$ pentapeptide $(12.1 \mathrm{mCi} / \mathrm{mmole}), 10 \mathrm{~mm}$ dithiothreitol, $0.1 \mathrm{M}$ tris- $\mathrm{HCl}$ buffer $(\mathrm{pH} 8.5)$ and $10 \mu \mathrm{l}$ of particulate fraction (153 $\mu \mathrm{g}$ of protein). Total volume: $35 \mu 1$.

\begin{tabular}{c|c}
\hline Addition* & $\begin{array}{c}\text { Lipid-P-P-MurNAc- } \\
\text { pentapeptide } \\
\text { cpm (\%) }\end{array}$ \\
\hline $\mathrm{Mg}^{2+}$ & $1,158(100)$ \\
$\mathrm{Mg}^{2+}+\mathrm{NH}_{4}{ }^{+}$ & $712(62)$ \\
$\mathrm{Mg}^{2+}+\mathrm{Li}^{+}$ & $791(68)$ \\
$\mathrm{Mg}^{2+}+\mathrm{Na}^{+}$ & $855(74)$ \\
$\mathrm{Mg}^{2+}+\mathrm{K}^{+}$ & $926(80)$ \\
$\mathrm{Mg}^{2+}+\mathrm{Rb}^{+}$ & $931(80)$ \\
$\mathrm{Mg}^{2+}+\mathrm{Cs}^{+}$ & $694(60)$ \\
\hline$*$ Concentrations of $\mathrm{MgCl}_{2}$ and monovalent
\end{tabular}
Concentrations of $\mathrm{MgCl}_{2}$ and monovalent cations (chloride) were $25 \mathrm{~mm}$ and $170 \mathrm{~mm}$, respectively. 
experiments, the reactions were stopped after 3 minutes unless otherwise stated, and the amounts of lipid-P-P-MurNAc-pentapeptide formed were determined.

The optimum $\mathrm{pH}$ for activity was determined to be about 8.5 as shown in Fig. 2. The activity was significantly weaker at $\mathrm{pH}$ values below 7.5 or over 9.0 .

The reaction required the presence of $\mathrm{Mg}^{2+}$ and an SH-protector and was unaffected by the addition of ATP (Table 1). The maximum activity was observed with $25 \mathrm{~mm} \mathrm{Mg}^{2+}$, but the activity decreased rather with over $25 \mathrm{~mm}$ of the ion as shown in Fig. 3, while the activity of the enzyme from $S$. aureus has been reported not to decrease even in the presence of over $25 \mathrm{~mm}$ of $\mathrm{Mg}^{2+12)}$. Since HEYDANEK et al.$^{8)}$ have reported that the transferase from $S$. aureus is activated with monovalent cations in addition to $\mathrm{Mg}^{2+}$, the effect of monovalent ions on the enzyme activity of B. megaterium KM was examined. As Table 2 shows, the cations tested inhibited the transferase from B. megaterium KM, distinguishing this enzyme from that of $S$. aureus. $\mathrm{NH}_{4}{ }^{+}$and $\mathrm{Cs}^{+}$(each $25 \mathrm{~mm}$ ) inhibited the enzyme by 38 and $40 \%$, respectively.

As shown in Table 1, the addition of UMP, another product of the reaction, suppressed the transfer reaction. The addition of increasing concentrations of UMP after 4 minutes of the initiation of the reaction resulted in the progressively increasing effect on the concentration of lipid-P-P-MurNAcpentapeptide present (Fig. 4). Furthermore, when UMP was added at zero time, the amount of lipid-P-P-MurNAc-pentapeptide formed was equivalent to that which remained when the same amount of UMP was added after 4 minutes. Thus, equilibrium conditions were reached by either route, indicating that the reaction is reversible.

Fig. 3. Effect of $\mathrm{Mg}^{2+}$ on the phospho-MurNAcpentapeptide-transferase activity.

The reaction mixture contained $0.11 \mathrm{~mm}$ UDPMurNAc- $\left[{ }^{3} \mathrm{H}\right]$ pentapeptide.

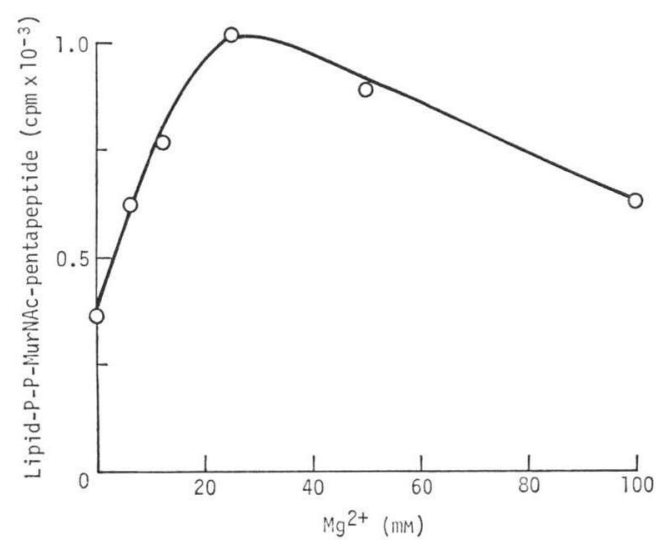

Fig. 4. Effect of UMP on lipid-P-P-MurNAcpentapeptide formation.

The concentration of UDP-MurNAc- $\left[{ }^{3} \mathrm{H}\right]$ pentapeptide was $0.11 \mathrm{~mm}$. The arrow shows the addition time for UMP or UDP. O, control (no UMP or UDP added); $\nabla, 1 \mu \mathrm{M}$ UMP; 圆, $10 \mu \mathrm{M}$ UMP; $\Delta, 100 \mu \mathrm{M}$ UMP; $\times, 100 \mu \mathrm{M}$ UDP; $\bullet$, $10 \mu \mathrm{M}$ UMP was added at zero time.

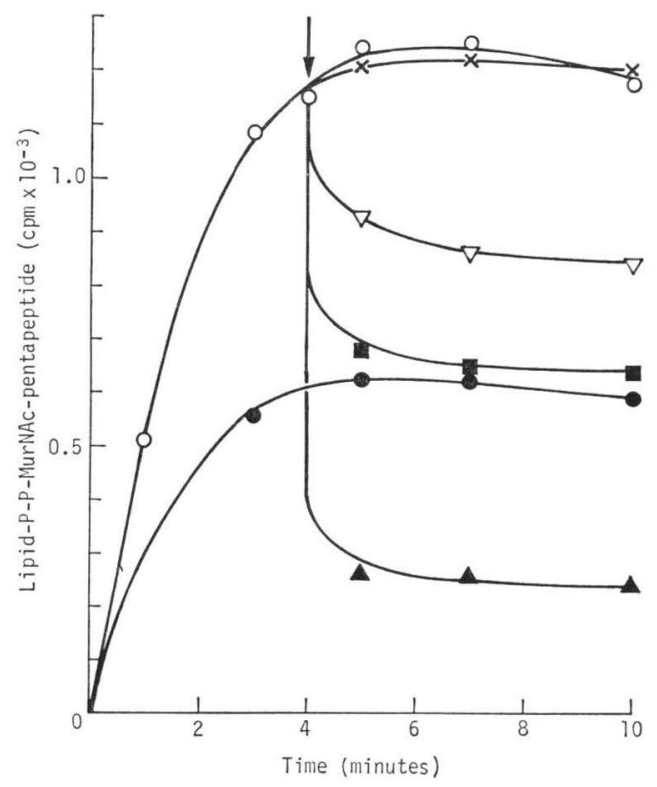

Mode of Inhibition of the Phospho-MurNAc-pentapeptidetransferase by Amphomycin

The authors ${ }^{3)}$ reported that amphomycin is a specific inhibitor of the transferase: it does not inhibit 
Table 3. Effect of amphomycin on the phosphoMurNAc-pentapeptide-transferase activity.

The concentration of UDP-MurNAc- $\left[{ }^{3} \mathrm{H}\right]$ pentapeptide was $0.33 \mathrm{~mm}$. Other conditions are described in the text.

\begin{tabular}{c|c}
\hline $\begin{array}{c}\text { Amphomycin } \\
(\mu \mathrm{g} / \mathrm{ml})\end{array}$ & $\begin{array}{c}\text { Lipid-P-P-MurNAc- } \\
\text { pentapeptide } \\
\text { cpm }(\%)\end{array}$ \\
\hline 0 & $1,945(100)$ \\
1 & $1,795(92)$ \\
10 & $1,622(83)$ \\
20 & $970(50)$ \\
50 & $311(16)$ \\
100 & $0(0)$ \\
\hline
\end{tabular}

Fig. 5. Inhibition of the transfer of phosphoMurNAc-pentapeptide from UDP-MurNAcpentapeptide (UDP-Mp) to lipid-P by amphomycin.

$$
\bigcirc \text {, no additions; with amphomycin }(30 \mu \mathrm{g} / \mathrm{ml}) \text {. }
$$
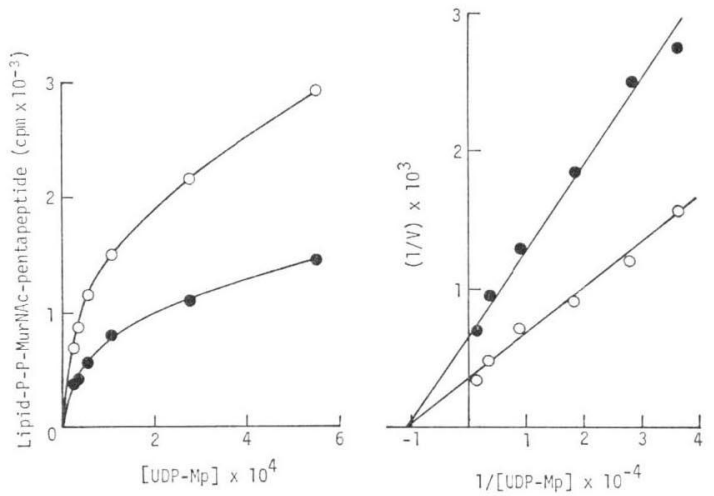

the formation of peptidoglycan from lipid-P-P-MurNAc-pentapeptide and UDP-GlcNAc. Table 3 shows the inhibition of the transferase activity by various concentrations of amphomycin. The mode of inhibition by amphomycin was then examined by measuring the formation of lipid-P-P-MurNAcpentapeptide from various concentrations of UDP-MurNAc-pentapeptide with or without amphomycin $(30 \mu \mathrm{g} / \mathrm{ml})$. As shown in Fig. 5, the LineweAver-Burk plot revealed that the antibiotic inhibits noncompetitively the reaction for the substrate UDP-MurNAc-pentapeptide. The $K m$ value of the enzyme was tentatively calculated from Fig. 5 to be $93 \mu \mathrm{M}$ for UDP-MurNAc-pentapeptide but it must be noted that the enzyme was not purified.

\section{Discussion}

The transferase of $B$. megaterium KM has the properties similar to those of $S$. aureus ${ }^{12)}$ with respect to optimum $\mathrm{pH}$ and $\mathrm{Mg}^{2+}$ requirement. However, it is differentiated from the enzyme of $S$. aureus by the finding that the $B$. megaterium enzyme is somewhat inhibited by monovalent cations and requires an $\mathrm{SH}$-protector (the $S$. aureus enzyme is stimulated by monovalent cations and does not require any $\mathrm{SH}$-protector).

Amphomycin is a specific inhibitor of cell wall peptidoglycan synthesis ${ }^{1,2)}$, inhibiting non-competitively the phospho-MurNAc-pentapeptide-transferase of B. megaterium for the substrate UDPMurNAc-pentapeptide. After the authors ${ }^{2}$ suggested that amphomycin-group antibiotics inhibit the formation of lipid intermediate in peptidoglycan synthesis, several reports concerning its mode of action have appeared. ELBEIN and coworkers ${ }^{13}{ }^{15)}$ reported that amphomycin inhibits the transfer of mannose from GDP-mannose and of GlcNAc from UDP-GlcNAc by particulate enzyme preparations from pig aorta ${ }^{13,14)}$, Mycobacterium smegmatis ${ }^{13)}$, and mung beans ${ }^{15)}$, and that tsushimycin, an amphomycin-group antibiotic, also inhibits the formation of dolichyl-P-mannose, dolichyl-P-Glc and dolichylP-P-GlcNAc with a particulate fraction from pig aorta ${ }^{16)}$.

On the other hand, tunicamycin ${ }^{17,13)}$ inhibits selectively the formation of polyisoprenol-P-P-GlcNAc in the biosynthesis of glycoproteins ${ }^{19,20)}$ and teichoic acid ${ }^{21)}$, and the phospho-MurNAc-pentapeptide-transferase of Micrococcus lysodeikticus ${ }^{22}$, but does not inhibit the transfer of mannose and glucose.

Thus, the mechanism of inhibition by amphomycin of the formation of lipid intermediate seems to be different from that by tunicamycin. A determination of mode of inhibition of the phosphoMurNAc-pentapeptide-transferase of B. megaterium by tunicamycin would be of interest. 


\section{References}

1) Ōmura, S.; H. TAnaka, M. Shinohara, R. ŌIwa \& T. Hata: Inhibition of bacterial cell wall synthesis by amphomycin. In Chemotherapy, Proc. 9th Int. Cong. Chemother., Vol. 5, pp. 365 369, Plenum Press, London, 1975

2) Tanaka, H.; Y. Iwai, R. Ōina, S. Shinohara, S. Shimizu, T. OKa \& S. Ōmura: Studies on bacterial cell wall inhibitors. II. Inhibition of peptidoglycan synthesis in vivo and in vitro by amphomycin. Biochim. Biophys. Acta 497: 633 640, 1977

3) TANAKA, H.; R. ŌIWA \& S. ŌMURA: Amphomycin inhibits phospho- $N$-acetylmuramyl-pentapeptide translocase in peptidoglycan synthesis of Bacillus. Biochem. Biophys. Res. Commun. 86: 902 908, 1979

4) Heinemann, B.; M. A. Kaplan, R. D. Muir \& I. R. Hooper: Amphomycin, a new antibiotic. Antibiot. Chemother. 3: 1239 1242, 1953

5) Bodanszky, M.; G. F. Sigler \& A. Bodanszky: Structure of the peptide antibiotic amphomycin. J. Am. Chem. Soc. 95: 2352 2357, 1973

6) Neuhaus, F. C.: Initial translocation reaction in the biosynthesis of peptidoglycan by bacterial membranes. Accts. Chem. Res. 4: 297 303, 1971

7) GeIs, A. \& R. PlaPP: Phospho- $N$-acetylmuramoyl-pentapeptide-transferase of Escherichia coli K12. Properties of the membrane-bound and the extracted and partially purified enzyme. Biochim. Biophys. Acta 527: 414 424, 1978

8) Heydanek, Jr., M. G.; R. Linzer, D. D. Pless \& F. C. Neuhaus: Initial stage in peptidoglycan synthesis. Mechanism of activation of phospho- $N$-acetylmuramyl-pentapeptide translocase of potassium ions. Biochemistry 9: 3618 3623, 1970

9) Reynolds, P. E.: Peptidoglycan synthesis in Bacilli. I. Effect of temperature on the in vitro system from Bacillus megaterium and Bacillus stearothermophilus. Biochim. Biophys. Acta 237: 239 254, 1971

10) Strominger, J. L.: Microbial uridine-5'-pyrophosphate $N$-acetylamino sugar compounds. I. Biology of the penicillin-induced accumulation. J. Biol. Chem. 224: 509 523, 1957

11) OKA, T.: Mode of action of penicillins in vivo and in vitro in Bacillus megaterium. Antimicrob. Agents Chemother. 10: 579 591, 1976

12) Struve, W. G.; R. K. Sinha \& F. C. Neuhaus: On the initial stage in peptidoglycan synthesis. Phospho$\mathrm{N}$-acetylmuramylpentapeptide translocase (uridine monophosphate). Biochemistry 5: 82 93, 1966

13) Kang, M. S.; J. P. Spencer \& A. D. Elbern: Amphomycin inhibits the incorporation of mannose and GlcNAc into lipid-linked saccharides by aorta extracts. Biochem. Biophys. Res. Commun. 82: 568 574, 1978

14) Kang, M. D.; J. P. Spencer \& A. D. Elbein: Amphomycin inhibition of mannose and GlcNAc incorporation into lipid-linked saccharides. J. Biol. Chem. 253: 8860 8866, 1978

15) Ericson, M. C.; J. T. Gafford \& A. D. Elbein: In vivo and in vitro inhibition of lipid-linked saccharide and glycoprotein synthesis in plants by amphomycin. Arch. Biochem. Biophys. 191: 698 704, 1978

16) Elbein, A. D.: The effect of tsushimycin on the synthesis of lipid-linked saccharides in aorta. Biochem. J. 193: $477 \sim 484,1981$

17) Takatsuki, A.; K. Arima \& G. Tamura: Tunicamycin, a new antibiotic. I. Isolation and characterization of tunicamycin. J. Antibiotics 24: 215 223, 1971

18) Ito, T.; A. Takatsuki, K. Kawamura, K. Sato \& G. Tamura: Isolation and structure of components of tunicamycin. Agric. Biol. Chem. 44: 695 698, 1980

19) Takatsuki, A.; K. Kohno \& G. Tamura: Inhibition of biosynthesis of polyisoprenol sugars in chick embryo microsome by tunicamycin. Agric. Biol. Chem. 39: 2089 2091, 1975

20) Heifetz, A.; R. W. Keenan \& A. D. Elbein: Mechanism of action of tunicamycin on the UDP-GlcNAc: Dolichyl-phosphate GlcNAc-1-phosphate transferase. Biochemistry 18: 2186 2192, 1979

21) Hancock, L. C.; G. Wiseman \& J. Baddiley: Biosynthesis of the unit that links teichoic acid to the bacterial wall: inhibition by tunicamycin. FEBS Lett. 69: 75 80, 1976

22) Tamura, G.; T. Sasaki, M. Matsuhashi, A. Takatsuki \& M. Yamasaki: Tunicamycin inhibits the formation of lipid intermediate in cell-free peptidoglycan synthesis of bacteria. Agric. Biol. Chem. 40: 447 449, 1976 